\title{
The Model of Game-based Learning in Fire Safety for Preschool Children
}

\author{
Nur Atiqah Zaini ${ }^{1}$, Siti Fadzilah Mat Noor ${ }^{2}$, Tengku Siti Meriam Tengku Wook ${ }^{3}$ \\ SOFTAM, Research Center for Software Technology and Management \\ Faculty of Information Science and Technology \\ Universiti Kebangsaan Malaysia \\ 43600 Bangi, Selangor \\ Malaysia
}

\begin{abstract}
The Model of Game-based Learning in Fire Safety developed for preschool children to educate them in learning fire safety issues. Due to the lack of awareness towards fire hazard, there are few factors that have arisen regarding this issue such as children's ages, experiences and knowledge. The main objective of this study is to identify the user requirements of preschool children in developing the Model of Game-Based Learning in Fire Safety. This study involved six preschool children of Tabika Kemas Kampung Berawan, Limbang Sarawak by using UserCentered Design method. The ability of cognitive, behavior and psychomotor skills are the main aspects to develop the model. Thus, to lower the risk of injuries during practical training in real situation, there is a need to educate them using the technology of tablet. Therefore, a prototype has been developed known as APi Game-Based Learning as a platform for children to learn about fire safety issues. Hence, this APi prototype developed to validate the Model of Game-Based Learning in Fire Safety development for preschool children. Thus, the finding of the study showed the engagement of children in learning fire safety through game improved their knowledge, behavior and psychomotor skills. Overall, this study makes an important contribution in determining the usability on the level of effectiveness towards preschool children through active learning.
\end{abstract}

Keywords-Game-based learning; fire safety; user-centered design; effectiveness

\section{INTRODUCTION}

Lack of awareness in potential fire hazards as the concern issues bring threat for the children. Addressing this need, the exposure of fire safety issues on the children led them to learn survival skills. In fact, fire hazard affects their lives, education and abilities. Many cases in Malaysia as reported by Fire Rescue Department of Malaysia showed the annual report of fire cases related with houses and buildings [1]. Due to the faulty of electricity as the highest factor of deadly fire occurred every year. Thus, by providing the information of fire hazard especially to children plays an important role to educate them and save lives as well. The importance of learning and teaching fire safety issues should be taken seriously to prevent injuries to the children.

These are the most common problems occurred that related with fire safety. There were caused by limited fire safety awareness, less training, fire protection systems were not provided and delayed on notifying the fire brigades [2]. Fires are always life-threatening and dangerous that risk people to save lives. Addressing these problems, a widespread implementation of teaching and learning using technology was focused to reduce injuries and fatalities among the people especially children.

In addition, there is a growing need for the preschool children to learn using technology instead of conveying the information through conventional way of teaching and learning [3]. Subsequently, technologies have been exposed all over the world and spread like wildfire by providing a lot of functionalities that contribute in helping people. Therefore, the development of interactive technology such as tablet led to continuous innovation of teaching and learning. Apparently, the technology itself stimulates creativity and often draws the attention of preschool children [4]. However, children are facing difficulties when using technology because of some constraints due to their abilities and growth development. Many applications developed to ease them in using technology and its use in education trained their cognitive and psychomotor skills [5], [6].

The implementation of applications that support learning helped the children to interact well with the systems. For example, the application of fire safety education in the form of gaming environment. Thus, the interactive learning such as game-based learning enhanced the children to improve interaction and learning in fire safety issues [7]. On the other hand, to provide them clearly on the risk of fire hazard that caused a lot of damages and death required an efficient way to identify their needs.

\section{LITERATURE REVIEW}

Game-based learning promoted interactive learning, which, derived from the use of computer games in delivering the educational value [8]. The main purpose of developing educational games and training simulators were using the same technical elements with different purpose of delivering information to the users. There were many applications developed in the form of gaming to educate the children in teaching and learning [9], [10], [11]. Realizing the best ways to attract the children to stay focus during learning session by providing multimedia elements such as animation and audio [12], [13], [14].

Getting feedback from the system while interacting, the children gave either positive or negative responses and kept on 
playing continuously. It showed that the engagement of the children by using their abilities to think and operate the technology themselves. Engagement obviously affect the ways of teaching and learning which, emphasizing the enjoyment and motivation of the users [15]. Meanwhile, the children who are actively participating in learning must be motivated to engage them with the use of sound [16]. It helped the learning environment to be more fun and interesting. To improve their interests in learning serious issue such as fire safety should be delivered through interactive learning to let them interact well with the system without feeling scared.

Therefore, fire safety is a growing concern issue among the youth especially children. They were highly-risk of exposure towards fire hazard and led into danger because of lack of knowledge and delay actions [17]. Thus, the fire safety education should be delivered in the form of gaming to lower the risk of injuries [18]. Serious games, virtual reality, mobile and computer games were used as a platform to promote the fire safety education. Hence, the learning session would be more entertaining at the same time delivering the main purpose of fire safety issues. It is crucial to provide high quality of education where they learned on the importance of evacuation time and basic skills to escape. Their responses towards the fire situations should be taken seriously. By providing an effective way to learn with the use of interactive devices absolutely attracts the children's interests in learning.

On the other hand, interactive devices demonstrated the children's creativity in solving problems. Due to their growth of psychomotor, age is the main element that will affect their performances in operating the devices [19]. However, the functionalities of the devices should be suitable for their ages and capabilities to use the technology. The fact that the children were still in growth development phase showed they were still having difficulties to control their hands and fingers movements precisely [20]. Focusing on the specific devices provided for children to convey the information will ease them to interact and give the positive responses with the system as well. In fact, the children's capabilities are also affecting their involvement and achievements [21]. The most concern issue was promoting fire safety education through interactive learning by using technology that suitable for the fine motor skills development of preschool children.

In this research, a technology of tablet supported learning where, it considered as one of the various ways that able to teach the children about fire safety education. As children nowadays have early contact with the tablet that led them to deal faster with the functionalities [22]. Thus, there were three main aspects focused that were cognitive, psychomotor and behaviour. These aspects were observed on preschool children to validate the effectiveness of fire safety education through the technology of tablet.

\section{METHOD}

Overall method used in this study was User-Centered Design (UCD) that focused on the involvement of the users from the early stage until the end of the experiment [23]. By using UCD method, four distinct phases involved the users throughout the design and development process. The following are the general phases of UCD process as shown in Fig. 1.

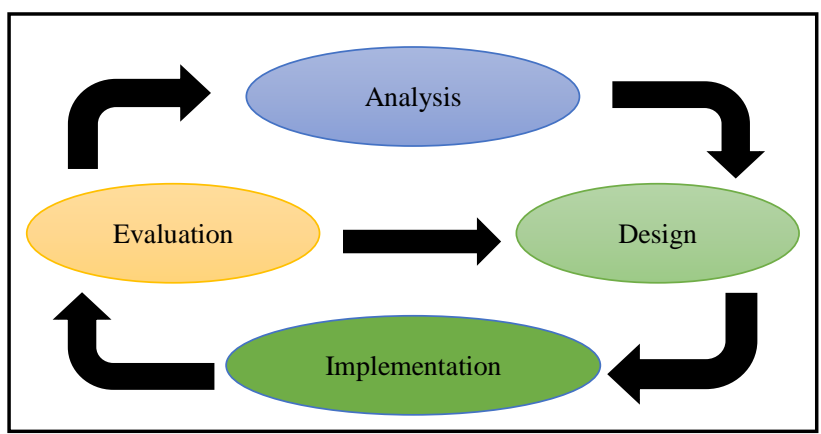

Fig. 1. User-Centered Design.

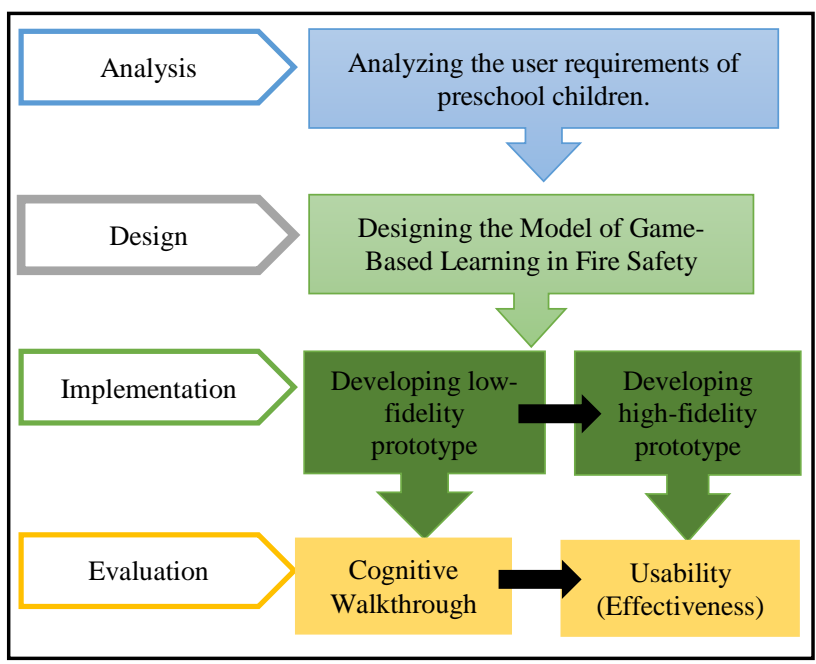

Fig. 2. Processes of Phases.

Meanwhile, Fig. 2 showed the processes of every phase involved in this research.

By following the processes of UCD method, all the user requirements needed were used to develop the model of gamebased learning in fire safety for preschool children. Knowing their limitations on using technologies should be focused to avoid difficulties during final testing conducted on them. Collecting the data was the crucial part to ensure that the end results achieved the objectives of the research. For the evaluation of cognitive walkthrough were tested on expert users through two techniques, observation and interviews. While, final evaluation of usability was tested on preschool children through observation and think aloud.

\section{A. Preliminary Study (Analysis Phase)}

The Model of Game-based Learning in Fire Safety was developed based on the user requirements obtained from the preliminary study conducted on the preschool children. By combining the results obtained from preliminary study and literature review, the model was developed specifically following the children's needs. This study involved six preschool children who were at the age of four to six years old from Tabika Kemas Kampung Berawan, Limbang Sarawak [24]. There were two types of existing fire safety games tested during the preliminary study, which, were shown in Table I. Based on the testing, some interaction styles issues in the existing games were analyzed to determine the research problems as well before conducting the experiment. 
TABLE. I. THE PROBlems OF EXISTING Fire SAFETy GAMES

\begin{tabular}{|c|c|c|}
\hline Types of Games & Initial Investigation & Issues of Interaction (Users) \\
\hline $\begin{array}{l}\text { Help Mikey } \\
\text { Make It Out }\end{array}$ & 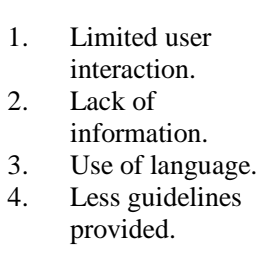 & $\begin{array}{l}\text { 1. User only interacted } \\
\text { with the limited button. } \\
\text { 2. The interface was quiet } \\
\text { confusing for the users. } \\
\text { 3. Less instruction for the } \\
\text { users on how to play. } \\
\text { 4. Difficulty of } \\
\text { understanding English. }\end{array}$ \\
\hline $\begin{array}{l}\text { Fire Safety } \\
\text { Challenge }\end{array}$ & 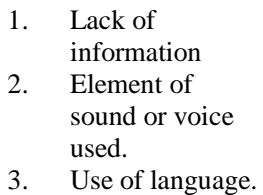 & $\begin{array}{l}\text { 1. No guidelines on how to } \\
\text { play. } \\
\text { 2. No instructions through } \\
\text { voice provided. } \\
\text { 3. Difficulty of } \\
\text { understanding English. }\end{array}$ \\
\hline
\end{tabular}

The interaction styles issues were identified after the games tested on the preschool children. Following the experiment conducted, the data was collected through observation and think aloud. As shown in Table II, the children played the games with different skills level. It showed that different ages of children placed some constraints on the ability of cognitive, behaviour and psychomotor skills when being tested by the existing fire safety games.

TABLE. II. ANALYSIS OF PRELIMINARY STUdY

\begin{tabular}{|c|c|c|}
\hline $\begin{array}{l}\text { Age of } \\
\text { Children }\end{array}$ & Help Mikey Make It Out & Fire Safety Challenge \\
\hline 4 years & $\begin{array}{l}\text { 1. Understand on how to } \\
\text { play the game but } \\
\text { needed more } \\
\text { explanation because of } \\
\text { the language used. } \\
\text { 2. Response towards the } \\
\text { game was slow because } \\
\text { of the instructions given } \\
\text { on how to play were not } \\
\text { clear. }\end{array}$ & 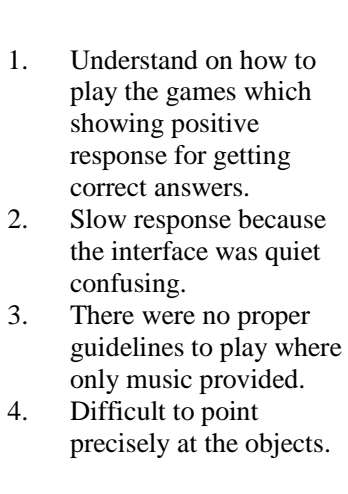 \\
\hline 5 years & 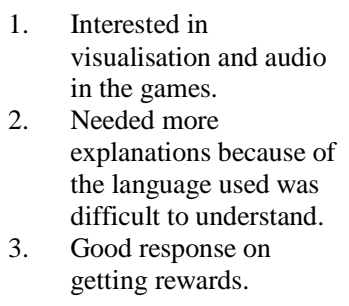 & $\begin{array}{l}\text { 1. Not really interested in } \\
\text { playing because no } \\
\text { voice instruction } \\
\text { provided. } \\
\text { 2. Able to point directly at } \\
\text { the objects. }\end{array}$ \\
\hline 6 years & $\begin{array}{l}\text { 1. Able to complete the } \\
\text { games after instruction } \\
\text { given. } \\
\text { 2. Slow response because } \\
\text { of the language used in } \\
\text { the game. }\end{array}$ & $\begin{array}{l}\text { 1. Enjoying the game } \\
\text { when getting reward. } \\
\text { 2. Able to control finger } \\
\text { movements precisely. } \\
\text { 3. Slow response because } \\
\text { of no instructions } \\
\text { provided. }\end{array}$ \\
\hline
\end{tabular}

Strategic Research Grant of KRA-2018-025, Faculty of Information Science \& Technology, Universiti Kebangsaan Malaysia.
TABLE. III. USER REQUIREMENTS

\begin{tabular}{|l|l|l|l|}
\hline User Requirements & $\mathbf{4}$ years & $\mathbf{5}$ years & $\mathbf{6}$ years \\
\hline User Interaction & $\checkmark$ & $\checkmark$ & $\checkmark$ \\
\hline Interface Design & $\checkmark$ & $\checkmark$ & $\checkmark$ \\
\hline Psychomotor (Fine Motor) & $\checkmark$ & $\checkmark$ & $\checkmark$ \\
\hline Cognitive (Knowledge) & $\checkmark$ & $\checkmark$ & $\checkmark$ \\
\hline Behaviour & $\checkmark$ & $\checkmark$ & $\checkmark$ \\
\hline $\begin{array}{l}\text { Gaming Elements (Reward, } \\
\text { Storyline, Player, Time) }\end{array}$ & $\checkmark$ & $\checkmark$ & $\checkmark$ \\
\hline $\begin{array}{l}\text { Multimedia Component (Animation } \\
\text { and Audio }\end{array}$ & $\checkmark$ & $\checkmark$ & $\checkmark$ \\
\hline Genre (Strategy) & $\checkmark$ & $\checkmark$ & $\checkmark$ \\
\hline Malay Language & $\checkmark$ & $\checkmark$ & $\checkmark$ \\
\hline
\end{tabular}

Besides, observation technique defined on observing their capabilities of solving the games. Meanwhile, think aloud was a process of determining the children's opinions on engagement and enjoyment of playing the games. Thus, the data collected can be implemented to develop the Model of Game-Based Learning in Fire Safety as shown in Table II and Table III.

Based on Table III showed that the user requirements obtained after carrying out the experiment on the existing fire safety games. All the user requirements were focused on children's abilities, gaming elements and gaming factors [3], [6], [15], [19], [22], [25], [26].

Analyzing all the user requirements for developing the model such as user interaction, interface design, psychomotor skills, cognitive, behavior, gaming elements, multimedia components. However, during the experiment conducted on the preschool children, they were facing trouble to understand English because they were not using English as the main language at home and school. All of the preschool children participated well in the experiment which, showing the positive responses towards fire safety games. Some of them were facing difficulties on interacting with the buttons must be designed specifically for children to play with ease.

\section{B. Model of Game-based Learning In Fire Safety (Design Phase)}

The Model of Game-based Learning in Fire Safety was developed based on the combination of Game-Based Learning Model [22], Fire Safety Model [27] and the user requirements obtained from the preliminary study as shown in Fig. 3.

\section{Game-based Learning Design Model:}

1) User: Preschool children at the age of four to six years old are required to testify the effectiveness of fire safety game.

2) Device: Tablet is a tool used as the device to test the game which, showed the compatibility with the children's fine motor skills and cognitive.

3) APi Fire Safety Game: It consists of game elements such as rewards, player, storyline, feedback, time, multimedia components to improve motivation, enjoyment and interactivity. Besides, interface design is focusing on menu 
driven to guide the children in using fire safety game by providing animation and sound. The voiceover was using Malay language.

4) Prototype: It consists of low-fidelity prototype and high-fidelity prototype.

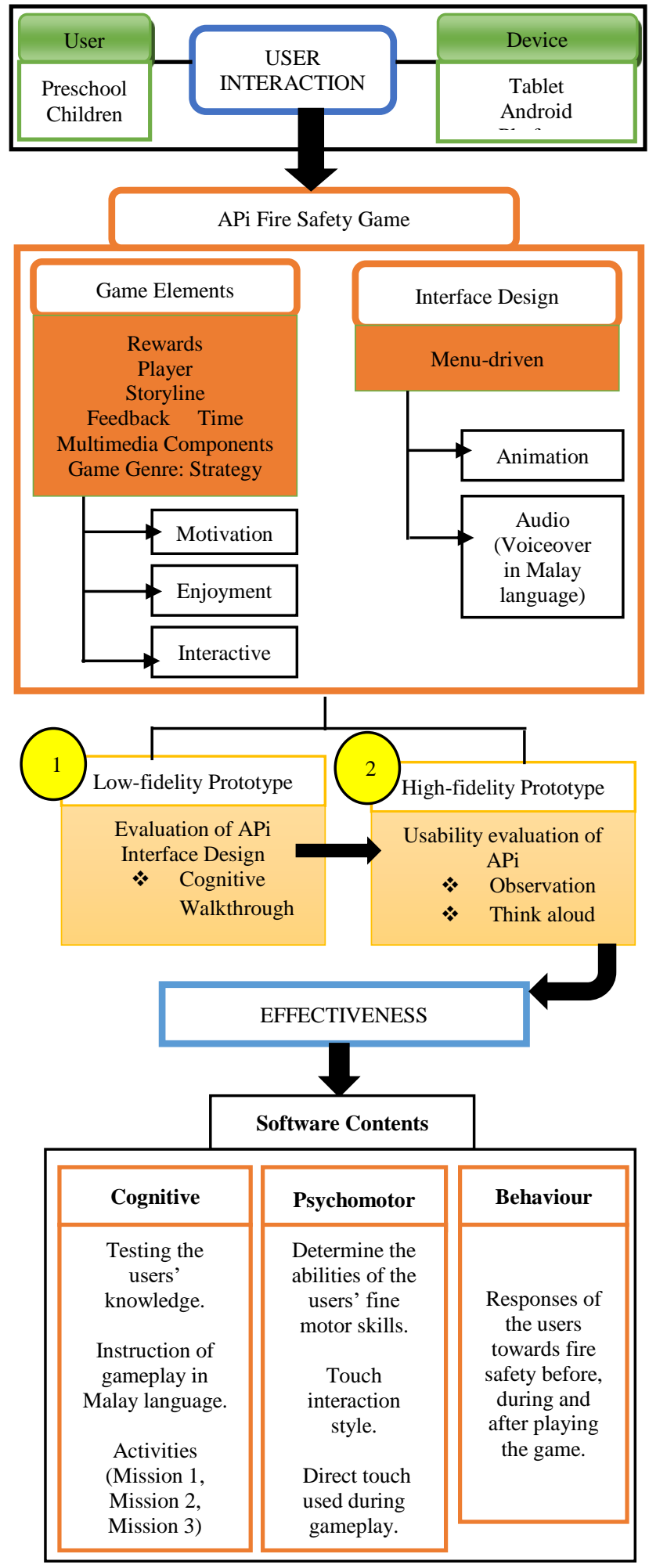

Fig. 3. Model of Game-Based Learning in Fire Safety for Preschool Children.
Software Contents: There are three aspects will be evaluated after testing the games that include behaviour, cognitive and psychomotor. Meanwhile, the effectiveness is the factor of usability used to validate the Model of GameBased Learning in Fire Safety.

The model consisted of three missions that required the users to complete. Mission 1 needed the users to identify the causes of fire accidents such as inflammable substances while Mission 2 conveyed the information on how to use fire extinguisher and the way to escape from fire in a trap house. Meanwhile, Mission 3 required the users to identify whom they should rescue if fire accident happened. All these missions provided for the users to learn and know the importance of fire safety issues. Every missions tested on the users would affect their cognitive, behaviour and psychomotor skills. Thus, all the missions created based on the learning module of Tabika KEMAS.

All the game elements were obtained based on suitable elements needed for preschool children [8]. During preliminary study showed that audio and animation were the most important elements for them to engage while playing the existing fire safety games. These game elements improved the children's motivation, enjoyment and playing interactive game. This APi fire safety game was developed in 2D which categorized in strategy and offline game [26]. Besides, the interface design was based on menu-driven to ensure the users understand the game flow of playing.

In addition, every mission in this game was following the module of learning at Tabika Kemas Kampung Berawan, Limbang Sarawak. The missions developed were suitable for the preschool children in terms of the gameplay and easy to understand the contents. This was because the APi fire safety game was using Malay language as the medium of interaction between the users and game. All the instructions were given by using audio instead of text because the limitation of the preschool children in reading.

There were two types of prototypes developed based on the model. It consisted of low-fidelity prototype and highfidelity prototype. In order to evaluate the low-fidelity of APi prototype, the cognitive walkthrough method was conducted on experts. This method used to improve the interface design of the prototype. While, to evaluate high-fidelity prototype were using observation and think aloud on the real users, the preschool children. This final evaluation used to evaluate the effectiveness of APi fire safety game tested on them.

The effectiveness of usability was evaluated based on cognitive, psychomotor and behavior of preschool children. Through the APi fire safety game, the children's abilities were tested in solving the missions with the use of tablet technology. The users' fine motor skills would be tested too to ensure that they could use touch interaction easily. With the use of APi fire safety game, their behaviors were evaluated before, during and after playing the game.

\section{Developing APi Prototypes}

In this section discussed on the prototype development which consisted of two processes, low-fidelity APi prototype and high-fidelity APi prototype. It was used to be named as 
APi because of the fire theme that related with fire safety issues. These prototypes were developed based on the model shown on Fig. 2 for preschool children and suitable with their ages, skills and knowledge. Both prototypes were designed using Adobe Photoshop and Unity 2017. APi prototypes emphasized more on the interaction style issues that needed to solve the research problems. Table IV and V showed the processes on developing the APi prototypes.

A low-fidelity prototype was not a fully functioning system developed for the users. This process was showing the early stage of development to test the functionality and interface design that suitable for the real users. Table IV showed the interface design of low-fidelity APi prototype.

TABLE. IV. LOW-FIDELITY PROTOTYPE

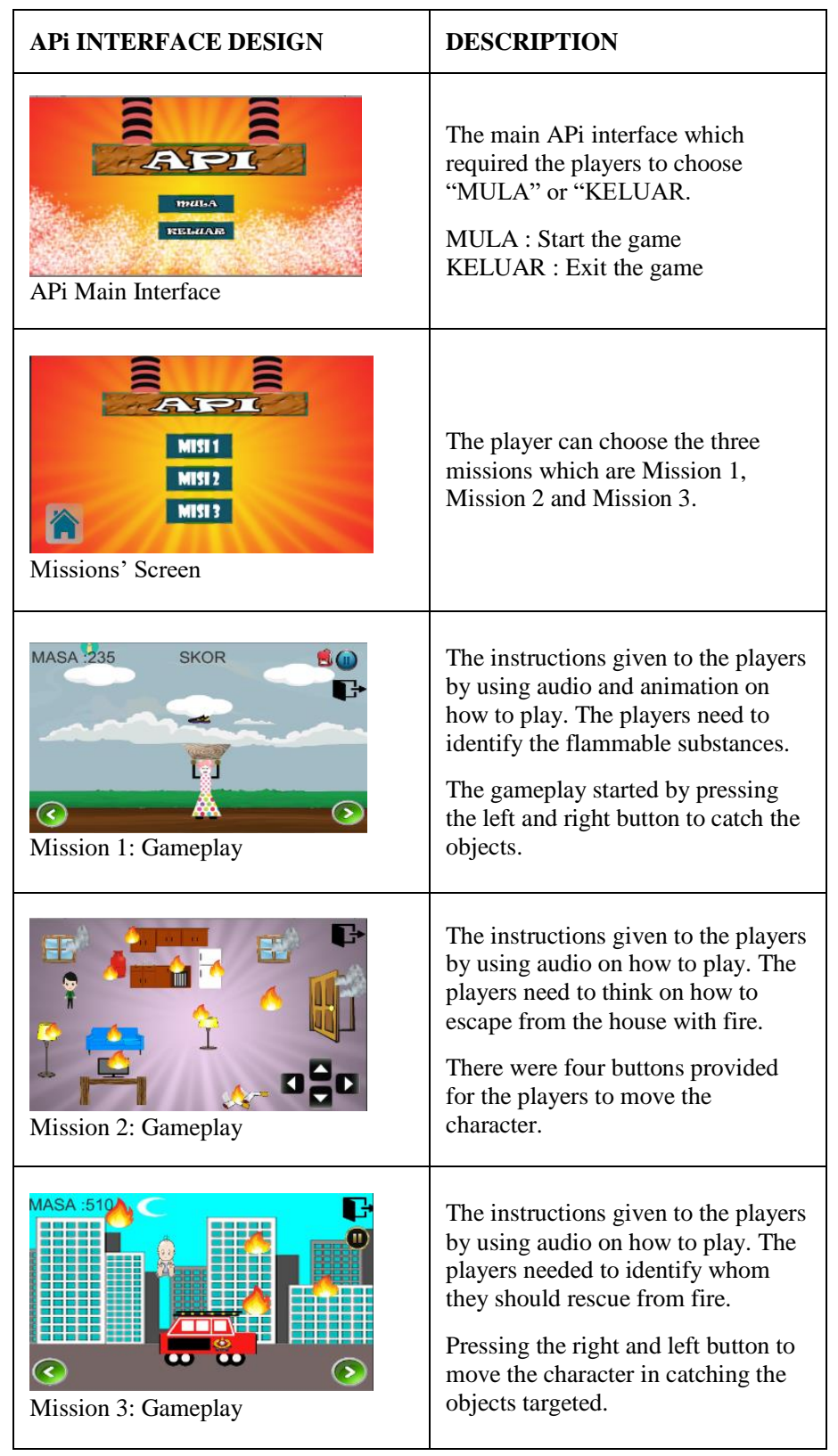

\section{Cognitive Walkthrough Method}

Extending to this low-fidelity APi prototype development, a Cognitive Walkthrough method was carried out to improve the weakness of the interface design [18], [28]. This process involved experts that consisted of two lecturers, two gamers and two graphic designers. Those experts needed to perform the tasks given to them in 20 minutes without discussing with other participants.

The experts were given the tasks to be completed during experiment along with the low-fidelity APi prototype. The tasks were shown below:

1) The participant needs to press the button "MULA" at the APi main interface to start the game.

2) There will be missions on the next screen which, consists of "MISI 1", "MISI 2" and "MISI 3". The participant needs to test the functionality of HOME button to go back to the main interface.

3) Next, the participant needs to choose "MISI 1" as the starting mission. The instruction will be given through audio before the mission has started. The participant needs to test the functionality of the button to proceed to the next screen.

4) The participant starts the "MISI 1" by pressing the "MULA" button and plays the game. Then, there are left and right button provided to move the character after the instructions given through audio.

5) After completing the "MISI 1", the participant can go to the mission screen by hitting the "OUT" button provided at the right side.

6) The participant will choose "MISI 2" for the next game. The instructions will be given through audio to guide the participant. There will be RIGHT and LEFT button provided to go to the next page.

7) The participant will be given instructions on how to play by using UP, DOWN, LEFT and RIGHT button provided.

8) After completing the "MISI 2", the participant can go to the mission screen by hitting the "OUT" button provided at the right side.

9) Next, the participant needs to choose "MISI 3" and the instruction will be given through audio before the mission has started. The participant needs to test the functionality of the button to proceed to the next screen.

10) The participant starts the "MISI 3" by pressing the "MULA" button and play the game. Then, there are RIGHT and LEFT button provided to move the character after the instructions given through audio.

11) After completing the "MISI 3", the participant can go to the mission screen by hitting the "OUT" button provided at the right side.

12) The participant will be rewarded by giving the badges after all the missions completed. Then, the participant needs to go back to the APi main screen by hitting the "OUT" button.

13)At the APi main screen, the participant can choose "KELUAR" to exit the game. 
As shown in Table $\mathrm{V}$ was the analysis of Cognitive Walkthrough conducted on the expert users.

Through the Cognitive Walkthrough method tested on the experts, there were some interaction and interface designs needed to be improved in low-fidelity APi prototype. Thus, it involved with the controller buttons, font and size, animation of the buttons, background image, consistency of button's position and visibility of the buttons.

The analysis showed that APi prototype had the features that suitable for the preschool children. The missions provided for them can be easily played with minimal supervision where, the children did not need to read the instructions of the game due to their capabilities in reading. This was because every instruction given to them through the audio.

As shown in Table VI were the high fidelity of APi prototype after cognitive walkthrough method was conducted on six experts.

TABLE. V. ANALYSIS OF COGNITIVE WALKTHROUGH

\begin{tabular}{|c|c|c|c|}
\hline CRITERIA & DESCRIPTION & AGREE & DISAGREE \\
\hline $\begin{array}{l}\text { Background } \\
\text { Theme }\end{array}$ & $\begin{array}{l}\text { 1. The background } \\
\text { colour. } \\
\text { 2. The use of } \\
\text { images as } \\
\text { background. }\end{array}$ & $\begin{array}{l}50 \\
50\end{array}$ & $\begin{array}{l}50 \\
50\end{array}$ \\
\hline Fonts & $\begin{array}{l}\text { 1. Font size } \\
\text { 2. Font type }\end{array}$ & $\begin{array}{l}50 \\
50\end{array}$ & $\begin{array}{l}50 \\
50\end{array}$ \\
\hline $\begin{array}{l}\text { Buttons } \\
\text { ("MULA, } \\
\text { KELUAR") }\end{array}$ & $\begin{array}{l}\text { 1. Size of button } \\
\text { 2. Consistency of } \\
\text { shape and size } \\
\text { 3. Animation style } \\
\text { of button }\end{array}$ & $\begin{array}{l}50 \\
33 \\
100\end{array}$ & $\begin{array}{l}50 \\
67 \\
0\end{array}$ \\
\hline $\begin{array}{l}\text { Controller } \\
\text { Button }\end{array}$ & $\begin{array}{l}\text { 1. The use of } \\
\text { button to move } \\
\text { character } \\
\text { 2. Consistency of } \\
\text { shape and size. } \\
\text { 3. Position of button }\end{array}$ & $\begin{array}{l}33 \\
17 \\
0\end{array}$ & $\begin{array}{l}67 \\
84 \\
100\end{array}$ \\
\hline Icon & $\begin{array}{l}\text { 1. To deliver the } \\
\text { information. }\end{array}$ & 83 & 17 \\
\hline Character & $\begin{array}{l}\text { 1. Referring to the } \\
\text { player } \\
\text { 2. The use of colour } \\
\text { 3. Size of characters }\end{array}$ & $\begin{array}{l}83 \\
50 \\
100\end{array}$ & $\begin{array}{l}17 \\
50 \\
0\end{array}$ \\
\hline Game Goals & $\begin{array}{l}\text { 1. The way of } \\
\text { playing and } \\
\text { delivering } \\
\text { information. }\end{array}$ & 100 & 0 \\
\hline Menus & $\begin{array}{l}\text { 1. The position of } \\
\text { menu } \\
\text { 2. The use of colour } \\
\text { 3. Animation style } \\
\text { of button }\end{array}$ & $\begin{array}{l}100 \\
83 \\
100\end{array}$ & $\begin{array}{l}0 \\
17 \\
0\end{array}$ \\
\hline Features & $\begin{array}{l}\text { 1. Missions } \\
\text { 2. Reward } \\
\text { 3. Time } \\
\text { 4. Score }\end{array}$ & $\begin{array}{l}100 \\
100 \\
100 \\
100\end{array}$ & $\begin{array}{l}0 \\
0 \\
0 \\
0\end{array}$ \\
\hline
\end{tabular}

TABLE. VI. HIGH-FidELITY PROTOTYPE

\begin{tabular}{|l|l|}
\hline DPSCRIPTION \\
\hline Mission 1: Gameplay
\end{tabular}

\section{RESULTS}

The development of the high-fidelity APi prototype was tested on the real users that were preschool children. At this evaluation of the APi prototype to evaluate the effectiveness of the Model Game-Based Learning in Fire Safety developed. The evaluation phase involved six participants of preschool children by using two techniques of observation and think aloud.

These techniques used to identify the reactions of the preschool children either they were able to complete all the missions in specific time given. The ways of responding to the game were the main part to evaluate the effectiveness of APi fire safety game tested on them. 
As shown in Table VII, the results showed on the score obtained while playing the APi fire safety game.

Meanwhile, Fig. 4 showed the three main aspects investigated in this study, which were cognitive, psychomotor, and behaviour of the preschool children. The usability testing was conducted to validate the effectiveness of the fire safety game-based learning model for preschool children. The percentage of cognitive aspect showed only $50 \%$ of preschool children at the age of 4 could accomplish Mission 1 due to the ability of memorizing the inflammable substances was still at the low level. $100 \%$ obtained for both 5 and 6 years ol d preschool children where, they could solve the problems completely.

For psychomotor aspect showed that all of preschool children were able to control their finger movements while playing the game. They could fix the hand-eye coordination although 4 years old children were having difficulties in handling the speed of the objects. Due to the growth development of fine motor skills, the children were trying to play with the buttons provided.

Based on the percentage showed that $50 \%$ of the preschool children at the age of 4 could finish the missions. They were showing positive response and engagement during playing session. However, some of them was easily distracted due to the frustration of the incapable getting the objects correctly. It led the children to give up on playing the game. Other than that, preschool children at the age of 5 and 6 years old showed the engagement and motivation while playing the game. They kept on responding to seek for help when facing danger. Thus, they were able to understand the dangers of fire that led them to injuries. Their behaviours were observed before, during and after playing the game.

Therefore, Table VIII showed the analysis of the usability testing evaluation on preschool children at the age of 4 to 6 years old. Every mission aligns all different activities to test their capabilities on cognitive, psychomotor and behaviour of the children.

TABLE. VII. SCORES OF THE API FIRE SAFETY GAME

\begin{tabular}{|l|l|l|l|l|l|l|}
\hline Mission & R1 & R2 & R3 & R4 & R5 & R6 \\
\hline Mission 1 & 50 & 50 & 100 & 100 & 100 & 100 \\
\hline Mission 2 & 100 & 100 & 100 & 100 & 100 & 100 \\
\hline Mission 3 & 50 & 50 & 100 & 100 & 100 & 100 \\
\hline
\end{tabular}

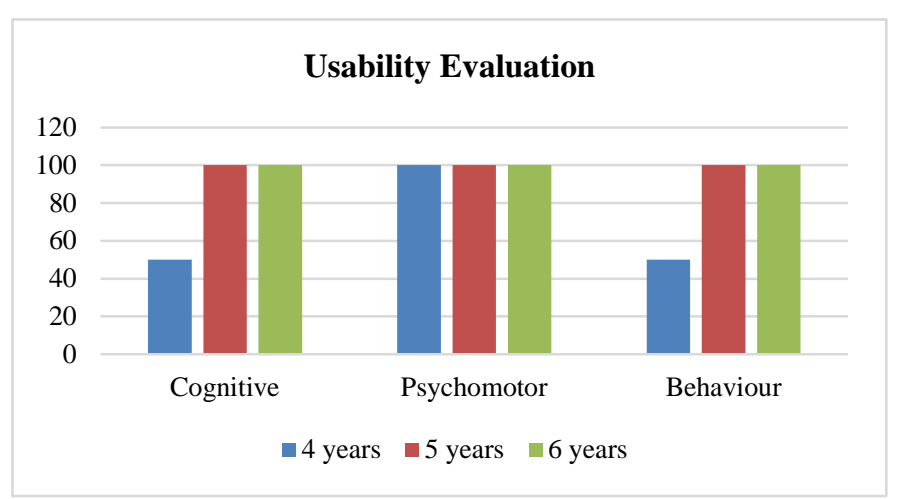

Fig. 4. Evaluation of usability Testing.
TABLE. VIII. HIGH-FIDELITY PROTOTYPE

\begin{tabular}{|c|c|c|c|}
\hline $\begin{array}{l}\text { Age of } \\
\text { Children }\end{array}$ & Cognitive & Psychomotor & Behaviour \\
\hline 4 years & $\begin{array}{l}\text { MISSION 1: } \\
\text { Some of them } \\
\text { were unable to } \\
\text { memorize the } \\
\text { inflammable } \\
\text { substances easily. } \\
\text { But still able to } \\
\text { complete the } \\
\text { mission to find } \\
\text { inflammable } \\
\text { substances. } \\
\text { MISSION 2: } \\
\text { Able to complete } \\
\text { the mission to } \\
\text { escape from the } \\
\text { burning house. } \\
\text { MISSION } 3 \text { : } \\
\text { Able to complete } \\
\text { the mission to } \\
\text { save lives of } \\
\text { human and } \\
\text { animal. }\end{array}$ & $\begin{array}{l}\text { MISSION 1: } \\
\text { A bit slower to } \\
\text { control the game } \\
\text { controller buttons. } \\
\text { But still able to } \\
\text { control the left and } \\
\text { right buttons but } \\
\text { facing difficulties } \\
\text { with the speed of } \\
\text { moving objects. } \\
\text { MISSION 2: } \\
\text { Able to control the } \\
\text { left and right } \\
\text { buttons easily. } \\
\text { MISSION 3: } \\
\text { A bit slower to } \\
\text { control the game } \\
\text { controller buttons. } \\
\text { But still able to } \\
\text { control the left and } \\
\text { right buttons but } \\
\text { facing difficulties } \\
\text { with the speed of } \\
\text { moving objects. }\end{array}$ & $\begin{array}{l}\text { MISSION 1: } \\
\text { Giving the positive } \\
\text { response towards } \\
\text { inflammable } \\
\text { substances. } \\
\text { MISSION 2: } \\
\text { Shouting loudly to } \\
\text { seek for help when } \\
\text { facing danger. } \\
\text { Happy to complete } \\
\text { the game. } \\
\text { MISSION 3: } \\
\text { Giving the positive } \\
\text { response to save } \\
\text { lives and the } \\
\text { engagement while } \\
\text { playing the game. }\end{array}$ \\
\hline 5 years & $\begin{array}{l}\text { MISSION 1: } \\
\text { Able to complete } \\
\text { the mission to find } \\
\text { inflammable } \\
\text { substances. } \\
\text { MISSION 2: Easy } \\
\text { to complete the } \\
\text { mission to escape } \\
\text { from the burning } \\
\text { house. } \\
\text { MISSION } 3 \text { : Able } \\
\text { to complete the } \\
\text { mission to save } \\
\text { lives of human } \\
\text { and animal. }\end{array}$ & $\begin{array}{l}\text { MISSION 1: } \\
\text { Able to control the } \\
\text { buttons easily } \\
\text { without } \\
\text { difficulties. } \\
\text { MISSION 2: } \\
\text { Able to control the } \\
\text { buttons easily to } \\
\text { move the } \\
\text { characters. } \\
\text { MISSION 3: } \\
\text { Able to control the } \\
\text { buttons easily with } \\
\text { the fast speed on } \\
\text { catching the } \\
\text { objects. }\end{array}$ & $\begin{array}{l}\text { MISSION 1: } \\
\text { The engagement of } \\
\text { the player to } \\
\text { remember every } \\
\text { inflammable } \\
\text { substance. } \\
\text { MISSION 2: } \\
\text { Afraid to solve the } \\
\text { game because of } \\
\text { the shouting voice } \\
\text { but still able to } \\
\text { point out the } \\
\text { escape door. } \\
\text { MISSION } 3 \text { : } \\
\text { Showed the } \\
\text { engagement of the } \\
\text { player to save lives } \\
\text { and happy to } \\
\text { complete the } \\
\text { game. }\end{array}$ \\
\hline 6 years & $\begin{array}{l}\text { MISSION 1: } \\
\text { Easy to complete } \\
\text { the mission to find } \\
\text { inflammable } \\
\text { substances. } \\
\text { MISSION 2: } \\
\text { Easy to complete } \\
\text { the mission to } \\
\text { escape from the } \\
\text { burning house. } \\
\text { MISSION 3: } \\
\text { Easy to complete } \\
\text { the mission to } \\
\text { save lives of } \\
\text { human and } \\
\text { animal. }\end{array}$ & $\begin{array}{l}\text { MISSION 1: } \\
\text { Facing no } \\
\text { difficulties in } \\
\text { handling touch } \\
\text { interaction with } \\
\text { the controlling } \\
\text { buttons. } \\
\text { MISSION 2: } \\
\text { Easy to handle all } \\
\text { the buttons } \\
\text { precisely to move } \\
\text { the character. } \\
\text { MISSION 3: } \\
\text { Facing no } \\
\text { difficulties in } \\
\text { handling touch } \\
\text { interaction with } \\
\text { the buttons. }\end{array}$ & $\begin{array}{l}\text { MISSION 1: } \\
\text { Know the } \\
\text { functions of } \\
\text { inflammable } \\
\text { substances and } \\
\text { showed the } \\
\text { engagement while } \\
\text { playing. } \\
\text { MISSION 2: } \\
\text { Shouting loudly to } \\
\text { seek for help to } \\
\text { escape from fire } \\
\text { and completing the } \\
\text { game easily. } \\
\text { MISSION 3: } \\
\text { Showed the } \\
\text { engagement while } \\
\text { playing to save } \\
\text { lives from fire. }\end{array}$ \\
\hline
\end{tabular}


The results showed that the children at the age of four years old have difficulties in controlling the speed of moving objects and game controller buttons. But they still managed to play the game till the end. For Mission 1 and Mission 3, either they were able to use touch interaction by using only one finger or two fingers on both hands. These missions let the children to focus by using hand-eye coordination activities.

For Mission 2, most of them completed the mission with ease by escaping from the burning house. It required the children to think as fast as they could to find the escape way. Some of them were shouting very loudly to seek for help. For Mission 3, it showed that the engagement of playing the game improved their attention span.

They tried to solve the mission with limited time. Thus, by scoring points in the game kept them motivated to play more. The children were able to hear the instruction given clearly and followed the gameplay. All these missions provided helped to stimulate their brains in solving problems if they were facing the fire hazard situation. Through this APi fire safety game helped the preschool children to improve awareness on fire safety issue at the early age. So that they noticed on how life-threatening fire is. It may cause injuries and death. By conveying the basic knowledge of fire safety on them through game environment, it helped them to engage more in learning.

Therefore, it showed the effectiveness of the Model GameBased Learning in Fire Safety developed. The preschool children understood the gameplay and learned the issue of fire safety with full of excitement. Based on the APi Game-Based Learning helped to improve their cognitive, psychomotor and behaviour towards fire safety issues. Learning fire safety issues through gaming environment improved their motivation too. Thus, game-based learning allowed better understanding of extremely dangerous effects of fire on children. In fact, educational game helped in promoting fire safety awareness.

\section{DISCUSSION}

Time was a crucial moment in handling fire situation. In fact, causing the risks of injuries and death could be reduced by providing the fire training simulator. Virtual reality based fire training simulator provided the general public and firefighters to train them in making decisions and organized responses towards fire safety [5]. By providing activities to achieve the goals of effectiveness, the users needed to perform training and experienced fire environments. Apparently, evacuation and rescue activities of fire situation at road tunnels were evaluated on the users. Based on the proposed framework, the functions and real-time performance of the simulator were verified. Their behaviours on initiating right actions were observed specifically in handling real fire situations.

Therefore, by accomplishing the missions or activities of fire safety helped the users to think as fast as they could in order to rescue themselves. Conveying the information of fire safety without harming the users was important to let them aware and initiate effective response towards danger. There were a lot of technologies used to deliver new methods of learning and training the fire safety education such as CAVE and computers [10]. In addition, these technologies used should be compatible with the users' abilities and skills.
Based on BIM (building information modelling) that supported by virtual reality and serious games exposed the users on awareness of emergency training [14]. By providing real-time fire evacuation guidance let the users to understand evacuation process. Three main aspects were focused which were real-time two ways information updates, real-time evacuation route and real-time location of building. Through the activities provided for the users to accomplish, their behaviours were taken seriously towards the experiment. The research highlighted the effective way of actions for human behaviour in emergent situations. The Model of Game-Based Learning in Fire Safety focused on the real-time game where it provided users to accomplish the mission within the limited time given. Hence, by playing the game would improve the children's ways of thinking and right actions taken.

In this Model of Game-Based Learning in Fire Safety research highlighted the three main aspects of preschool children which were cognitive, psychomotor and behaviour towards fire hazard. Through gaming environment attracted them to engage well with the missions provided in APi prototype. Concerning the fact that children have limited capabilities compared to adults, all the missions created were suitable for their ages, knowledge and skills [20]. Thus, they could solve the missions in given time to test their skills in handling the technology of tablet. By using the touch interaction could identify their psychomotor of fine motor skills and capabilities. APi prototype provided learning through game environment to verify the model developed.

The usability evaluation showed the effectiveness of APi prototype tested on the preschool children to educate them in learning fire safety issues. The preschool children were able to complete the mission with minimal supervision. On the other hand, some of them were facing difficulties in controlling the buttons. It happened because of the speed of the moving objects. Overall, all the preschool children showed positive response towards fire hazard and knew the basic skills to escape from danger.

APi prototype was developed based on the user requirements of the Model of Game-Based Learning in Fire Safety. Therefore, all multimedia components used such as audio and animation in developing the APi prototype eventually helped the preschool children to stay focus while playing. Audio and animation aroused their attentions and engaged them to play longer. With the instructions given to them by using voice, the preschool children did not need to read the instructions because some of them were still having difficulties in reading progress. While, the use of technology tablet attracted the preschool children to play because of their ages to explore the surrounding.

Extending to this research, we hoped that the Model of Game-Based Learning in Fire Safety can be used in other disaster such as flood to guide the preschool children. They need to be exposed and trained well from the early age as the prevention from danger situation. This is because the children are highly-risk towards fire hazard that can cause damages and death. With this in mind, saving lives are important by doing the right actions. 


\section{CONCLUSION}

This study indicates the development of the Model of Game-Based Learning in Fire Safety for preschool children. All the user requirements needed should be discussed more in order to train them on fire safety issues. Due to the lack of awareness towards fire hazard, there is a need to educate them in the form of edutainment to lower the risk of injuries.

Therefore, the preschool children needed to be exposed well and alerted on how life-threatening fire is. Despite the design of the Model of Game-Based Learning in Fire Safety promoted on the fire safety awareness. Hence, it helped to foster the children's learning process in their daily lives. Further study should be directed towards addressing on how the model can be improved based on children's needs such as cognitive, psychomotor and behavior aspects.

\section{ACKNOWLEDGMENT}

This work was supported under the Strategic Research Grant of KRA-2018-025, Faculty of Information Science \& Technology, Universiti Kebangsaan Malaysia.

\section{REFERENCES}

[1] Azman, I. \& Mohd Ridwan, A. R., "Performance-based reward administration as an antecedent of job satisfaction: A case study of Malaysia's fire and rescue agencies," Malaysian Journal of Society and Space, vol 7, pp. 107-118, 2016.

[2] Marrion, C. E., "More effectively addressing fire/disaster challenges to protect our cultural heritage," Journal of Cultural Heritage, vol 20, pp. 746-749, July 2016.

[3] Noorhidawati, a., Ghalebandi, S. G., and Siti Hajar, R, "How Do Young Children Engage with Mobile Apps? Cognitive, Psychomotor, and Affective Perspective," Journal of Convergence Information Technology, vol 87, pp. 385-395, July. 2015.

[4] Wei, W.J., \& Lee, L.C., "Interactive technology for creativity in early childhood education," Jurnal Teknologi, vol 75(3), pp 121-126, Nov. 2015 .

[5] Morrongiello, B. a., Schwebel, D. C., Bell, M., Stewart, J., \& Davis, A. L., "An evaluation of The Great Escape: Can an interactive computer game improve young children's fire safety knowledge and behaviors?," Health Psychology, vol 31, pp 496-502, Apr. 2012.

[6] He, Q., Hong, X., Zhao, G., \& Huang, X., “An Immersive Fire Training System Using Kinect," in Proceedings of the 2014 ACM International Joint Conference on Pervasive and Ubiquitous Computing: Adjunct Publication, 2014, paper 14, p. 231-234.

[7] Chin, L. C., \& Effandi Zakaria, "Development and Validation of the Game-Based Learning Module to Enhance Mathematics Achievement, Positive Learning Behaviours and Pro Social Behaviours," Journal of Science And Mathematics Letters, vol 2, pp. 23-31, Jan 2014.

[8] Tang, S., Hanneghan, M., \& El Rhalibi, A., Introduction to games-based learning, Games Based Learning Advancements for Multi-Sensory Human Computer Interfaces, New York: IGI Global, 2009.

[9] Green, C. S., Kattner, F., Eichenbaum, A., Bediou, B., Adams, D. M., Mayer, R. E., \& Bavelier, D., "Playing Some Video Games but Not Others Is Related to Cognitive Abilities: A Critique of Unsworth et al. (2015)," Psychological Science, vol 28, pp. 679-682, 2017.

[10] Williams-Bell, F. M., Kapralos, B., Hogue, A., Murphy, B. M., \& Weckman, E. J., "Using Serious Games and Virtual Simulation for Training in the Fire Service: A Review," Fire Technology, vol 51, pp. 553-584, March 2015.
[11] Tsai, M. H., Wen, M. C., Chang, Y. L., \& Kang, S. C., "Game-based education for disaster prevention," AI and Society, vol 30, pp. 463-475, Nov 2015.

[12] Noorhidawati, a., Ghalebandi, S. G., and Siti Hajar, R, "How Do Young Children Engage with Mobile Apps? Cognitive, Psychomotor, and Affective Perspective," Journal of Convergence Information Technology, vol 87, pp. 385-395, July. 2015.

[13] He, Q., Hong, X., Zhao, G., \& Huang, X., “An Immersive Fire Training System Using Kinect," in Proceedings of the 2014 ACM International Joint Conference on Pervasive and Ubiquitous Computing: Adjunct Publication, 2014, paper 14, p. 231-234.

[14] Wang, B., Li, H., Rezgui, Y., Bradley, A., and Ong, H. N., "BIM based virtual environment for fire emergency situation,", The Scientific World Journal, pp 22, Aug. 2014.

[15] Abdul Jabbar, A. I., \& Felicia, P., "Gameplay Engagement and Learning in Game-Based Learning: A Systematic Review," Review of Educational Research, vol 85, pp 740-779, 2015.

[16] Kamarudin, D., Hussain, Y., Applegate, E. B., \& Yasin, M. H. M., “An Ethnographic Qualitative Study On The Malaysian Preschool And Special Needs Children's Home And School Reading Habits," International Journal of Pedagogy and Teacher Education (IJPTE), vol 2, pp. 224-234, April 2018.

[17] Towers, B., "Children's knowledge of bushfire emergency response," International Journal of Wildland Fire, vol 24, pp 179-189, March 2015.

[18] Zaini, N.A., Noor, S.F.M, Wook, T.S.M.T, "Evaluation of APi Interface Design By Applying Cognitive Walkthrough,” International Journal of Advanced Computer Science and Applications, vol 10, 2019.

[19] Zainab, H, "Study of Touch Gesture Performance by Four and Five Year-Old Children: Point-and-Touch, Drag- and-Drop, Zoom-in and Zoom-out, and Rotate," Information Tech. thesis, Minnesota State University, Mankato, July 2014.

[20] Anthony, L., Brown, Q., Nias, J., Tate, B., Mohan and S., "Interaction and recognition challenges in interpreting children's touch and gesture input on mobile devices," in Proceeding of the 2012 ACM International Conference on Interactive Tabletops and Surfaces - ITS'12, 2012, p. 225.

[21] Sung, H.-Y., \& Hwang, G.-J., "A Collaborative Game-based Learning Approach to Improving Students' Learning Performance in Science Courses," Computers \& Education, vol 63, pp. 43-51, Nov 2012.

[22] Shi, Y.-R., \& Shih, J.-L., "Game Factors and Game-Based Learning Design Model," International Journal of Computer Games Technology, pp 1-11, Aug 2015.

[23] Preece, J., Sharp, H., Rogers, Y., Interaction Design: Beyond HumanComputer Interaction, vol 4, United Kingdom: Wiley, 2015.

[24] Zaini, N.A., Noor, S.F.M, Wook, T.S.M.T, "The User Requirements of Game-Based Learning in Fire Safety for Preschool Children," Journal of Advanced Science Letters, vol 24, pp. 7795-7799, Oct 2018.

[25] Singh, D. K. A., Ab Rahman, N. N. A. A., Rajikan, R., Zainudin, A., Mohd Nordin, N. A., Karim, Z. A., \& Yee, Y. H., "Balance and motor skills among preschool children aged 3 to 4 years old," Malaysian Journal of Medicine and Health Sciences, vol 11, pp. 63-68, Jan 2015.

[26] Oh, S. J., Fritz, M., \& Schiele, B., “Adversarial Image Perturbation for Privacy Protection A Game Theory Perspective," in Proceedings of the IEEE International Conference on Computer Vision, 2017, p. 14911500 .

[27] Wang, K.-C. ., Shih, S.-Y. ., Chan, W.-S. ., Wang, W.-C. ., Wang, S.-H., Gansonre, A.-A., Yeh, M.-F., "Application of building information modeling in designing fire evacuation-a case study," in 31st International Symposium on Automation and Robotics in Construction and Mining, ISARC 2014 - Proceedings, (Isarc), 2014, p. 593-601.

[28] Wook, T. S. M. T., Mohamed, H., Judi, H. M., and Ashaari, N. S., "Applying cognitive walkthrough to evaluate the design of SPIN interface," Journal of Convergence Information Technology, vol 7, pp. 106-115, March 2012. 